\title{
Which Corporate Social Responsibility Performance Affects the Cost of Equity? Evidence from Korea
}

\author{
Youngkyung $\mathrm{Ok}^{1}{ }^{1}$ a and Jungmu $\mathrm{Kim}^{2, *}$ (1) \\ 1 DGB Research Institute, 111, Oksan-ro, Buk-gu, Daegu 41593, Korea; okggaeng0208@gmail.com \\ 2 School of Business, Yeungnam University, 280 Daehak-Ro, Gyeongsan, Gyeongbuk 38541, Korea \\ * Correspondence: jungmu@yu.ac.kr; Tel.: +82-53-810-2843
}

Received: 9 March 2019; Accepted: 13 May 2019; Published: 23 May 2019

\begin{abstract}
This study analyzes the effect of corporate social responsibility activities on the cost of equity in Korea. We find that firms with better corporate social responsibility (CSR) performance generally exhibit cheaper equity financing. Considering three dimensions of CSR separately, we find that a higher "socially responsible management" significantly reduces the cost of equity by $1.13 \%-1.37 \%$ per annum and "Corporate governance" activity also marginally affects the cost of equity, while "environmental management" has no impact. Our result is robust in controlling for systematic risk, size, leverage ratio, and the number of analysts. These results imply that enhancing socially responsible management and corporate governance can increase firm value in Korea, but environmental management is not relevant for firm values. Putting differently, investors tolerate a lower return from firms with more CSR activities, because they expect them to provide sustainable incomes. Future researches can extend our approach to examining the effect on the cost of debt and cost of capital.
\end{abstract}

Keywords: cost of equity; CSR; ESG; sustainability; firm value

\section{Introduction}

Over the last decade, corporate social responsibility (CSR) has emerged as a dominant paradigm in business and scholarship as the growth in the number of indices, institutional investors, and mutual funds, make investment decisions depending on firms' CSR performance [1]. The CSR concept has been defined in various ways. McWilliams and Siegel [2] define it as action that appears to further some social good beyond the interests of the firm and legal requirements. Hill et al. [3] define it as firms' economic, legal, moral, and philanthropic actions.

Corporate social responsibility is a crucial issue in financial markets. Many studies have examined the relation between CSR performance and firm value in advanced markets. However, the literature has failed to provide consistent empirical findings about whether CSR performance affects firm value. Feldman et al. [4] argue that investors perceive firms with superior environmental performance as being less risky. Guenster et al. [1] insist that environmental performance and firm value are positively related, and Jiao [5] and Orlitzky et al. [6] find evidence of a positive relationship between CSR performance and firm value. On the other hand, Brammer et al. [7] argue that the realized returns of firms with higher CSR performance are low, while Hamilton et al. [8] and Nelling and Webb [9], find that CSR performance does not affect financial performance.

Most studies examine how CSR performance is evaluated by investors in stock markets, and few studies analyze how it is evaluated by participants in capital markets. Firms must be managed so as to maximize shareholder wealth. This necessarily incurs costs. Therefore, it is essential to examine the effects of CSR on financial performance explicitly. We thus analyze the relationship between CSR and financial performance, by examining whether CSR performance affects the firm's cost of equity. 
Similar to the studies conducted by Renneboog et al. [10] and Ghoul et al. [11], we verify that, firms with higher CSR performance can finance their equity capital at a cost lower than that paid by firms with lower CSR. If CSR performance can lower the cost of equity, this would provide firms a motive for being more active in CSR activities.

Previous studies measure CSR performance in various ways. Most studies that focus on the Korean stock market use the Korea Economic Justice Institute (KEJI) index, developed by the Economic Justice Research Institute as a proxy for CSR performance [12-14]. Several recent studies use the environmental management, social responsibility management, and governance (ESG) grades announced by the Korea Corporate Governance Service (KCGS) [15-20]. While the KEJI index provides information on only 200 firms, the KCGS announces the ESG grades for all firms listed on Korea Composite Stock Price Index (KOSPI). Using such large data can reduce sample bias. In addition, since ESG grades reflect the total CSR performance, as well as performance in three areas (environmental management, socially responsible management, and governance), using them allows us to observe how performance in each area affects the cost of equity.

Firms' cost of equity is essential information, not only for investors, but for the firms themselves. Firms use the weighted average cost of capital (WACC) in their investment decisions. Financial managers also consider the impacts on the cost of equity when deciding on voluntary disclosure [21]. Firms with effective governance and rigorous disclosure standards mitigate information asymmetry, lower agency costs, and ultimately reduce the cost of equity [22-24]. Cost of equity is also important information for investors, because they consider it as an opportunity cost when making investment decisions. Thus, examining the relationship between CSR performance and the cost of equity is important.

The Capital Asset Pricing Model (CAPM), or dividend discount model, is the most widely used method for estimating the cost of equity [25]. However, as the CAPM uses realized returns as a proxy for expected returns, many argue that it is not an appropriate estimation method, because the market beta has limitations in explaining future returns $[14,26,27]$. Thus, recent studies estimate the cost of equity through the Ohlson and Juettner [28] model, based on Gode and Mohanram [29], the Easton's [30] PEG model, or the MPEG model. These models are ex-ante estimation methods that derive the cost of equity through current stock prices and future earnings estimates. In this study, we use these ex-ante models to minimize measurement errors in the cost of equity.

This study contributes to the recent literature on the relationship between CSR performance and firm value, by focusing on whether CSR performance reduces the cost of equity in the Korea stock market. The reason why we focus on the Korean market is as follows. The family controlled large conglomerate groups, so called chaebol, have dominated the economy of South Korea. It is necessary to conduct research independently from other markets, such as the United States and Europe, since the chaebol are very unique business structures, existing only in the Korean financial market. There are several studies showing that the existence of chaebols affects the empirical results of corporate finance studies [31-38]. In particular, Campbell and Keys [31] point out the fact that Gibson's [39] study, which analyzes the relationship between the corporate performance and top executive turnover in emerging markets, includes South Korea in his sample, without considering chaebols. Therefore, the examination of the effects of CSR in South Korea, is not a simple repetition of papers conducted in other developed markets. It is worth examining if the well-known facts are still valid in the economy with a unique corporate governance structure or if there is something different.

Our main findings are as follows. In the Korean stock market, CSR performance does not directly affect the cost of equity. After dividing firms into "high" and "low", according to CSR performance, we find that firms with higher performance in socially responsible management or better corporate governance can finance the cost of equity at costs $1.36 \%$ to $1.89 \%$ lower than those paid by firms with lower performance. This indicates that investors are willing to invest even if these firms have lower expected returns. However, the cost of equity is also influenced by sensitivity to systematic risk, firm size, leverage ratio, and the number of analysts. Our findings imply that 
socially responsible management and better corporate governance play more important roles than environmental performance plays in the Korean stock market.

\section{Theoretical Background}

Previous studies have failed to provide consistent results concerning how CSR performance affects financial or capital markets. One set of results finds a positive relationship between CSR performance and financial performance. Statman and Glushkov [40] show that, portfolios with high CSR performance generally generate higher returns, than portfolios with low CSR performances. Gompers et al. [41] also suggest that firms with effective governance outperform firms with poor governance. Kempf and Osthoff [42] find that, firms with better CSR performance show positive excess returns, and Eccles et al. [43] show a positive relationship between CSR and firms' financial performance. Halvarsson and Zhan [44] and Yoon et al. [20] argue that, firms with higher CSR performance have lower cost of capital in the Swedish capital market. Consistent with previous researches, $\mathrm{Xu}$ et al. [45] make the same conclusion in the Chinese market.

Another set of results finds a negative relationship between CSR performance and financial performance. Brammer et al. [7] argue that firms with high CSR ratings tend to provide lower returns, but the results are insignificant. Renneboog et al. [10], and Hong and Kacperczyk [46] show that SRI funds or SRI-screened portfolios underperform benchmarks.

Another view is that CSR performance has no impact on firm performance. Humphrey et al. [47] find no difference in risk-adjusted performance between portfolios comprising high corporate social performance firms and those comprising low corporate social performance firms. They find that firms with high CSR performance tend to be large, and that they can lower systematic risk. Several studies, including [8,48], and [49], find no difference between socially responsible investment (SRI) mutual funds/indices and conventional ones.

\section{Data and Methodology}

\subsection{Data}

This study analyzes firms that have earned an ESG grade, from the KCGS, between 2011 and 2017. We attempted to analyze as many firms as possible. The KCGS started announcing ESG grades in 2011. However, as estimating the cost of equity requires a consensus one year later, all the 2018 data are used.

Specifically, the data used for this study are as follows: Daily and monthly dividend adjusted returns, prices, dividends per share, total assets, total debt, market capitalization, and analyst earnings forecasts. Market returns are calculated as the average of the returns of all stocks traded on KOSPI on day $t$. The three-year government bond yield is used as a proxy for the risk-free rate. All data except ESG grades are obtained from FnGuide. Data on ESG grades are taken from the KCGS.

To minimize measurement errors and outliers, estimates corresponding to the upper $1 \%$ and lower $1 \%$ of the cost of equity are excluded from the sample. To reduce the influence of extreme values, all control variables are winsorized at $1 \%$ and $99 \%$ each year.

\subsection{CSR Performance}

It is difficult to measure CSR performance, since the scope and definition of CSR is very diverse [50]. Some databases such as Kinder, Lyndenberg and Domini (KLD), Bloomberg, and Thomson Reuters Eikon have provided data on CSR performance of international corporations. Among them, KLD is the most widely used data source [11,51-53]. However, Yoon et al. [20] argued that ESG grades, published by these databases, have limitations in examining the Korean stock market, since they do not cover a wide range of ESG information on Korean firms.

Thus, we use ESG grades by KCGS as a proxy for CSR performance. Previous studies, which analyze the relations between CSR performance and the firm values on Korean stock markets, have employed the KEJI index or ESG grades as proxy for CSR performance. Earlier studies mainly 
used KEJI index by the Korea Economic Justice Institute [12-14]. However, it has been pointed out that it is difficult to analyze specifically the relationship with CSR performance, since KEJI index provides information on only 200 firms. Recent studies have used the ESG grades announced by the KCGS [15-20]. KCGS covers the largest number of firms among those listed in KOSPI, as well as selected firms listed in KOSDAQ, resulting in reduction of the sample bias.

The KCGS announces grades on environmental management, socially responsibility management, and corporate governance, every year, in order to help firms improve their level of sustainable management. KCGS uses seven grades (, , A+, A, B+, B, C, and D). However, for all areas, except governance, KCGS makes public the grade as "below B" for all grades of B, C, or D. Many governance indicators can be drawn directly from business reports, but other data can be evaluated only through voluntary disclosure. All KOSPI-listed firms are included in the evaluation. In addition, large-cap stocks (KOSDAQ 100), financial companies, companies belonging to large firms, and the firms that institutional investors request to be graded are also included in the evaluation.

The KCGS evaluates CSR performance for three areas: Environmental responsibility, social responsibility, and governance performance. These three factors are evaluated separately. In assessing around 900 listed firms, the KCGS consults data available via corporate disclosure (e.g., business reports, sustainability reports, and firms' websites) and media coverage. After an initial evaluation on 13 major categories, an analysis, using 237 core evaluation criteria and in-depth evaluation, are conducted simultaneously. The final grades are the sum of the environmental, social, and governance scores. The ESG grades are published annually.

Table 1 shows the statistics for firms that earned ESG grades from 2011 to 2017. A total of 4907 firms were evaluated over seven years, but only 4726 received ESG grades. Of these, 799 firms received an ESG grade at least once during the sample period. Only about $1 \%$ of firms earned $\mathrm{A}+$, and about $80 \%$ earned B or lower. In 2017, Shinhan Holdings was the only company to receive an S grade.

Table 1. Sample Distribution by Year and ESG Grade.

\begin{tabular}{|c|c|c|c|c|c|c|c|c|c|c|c|c|c|c|}
\hline \multicolumn{15}{|c|}{ Panel A: By Total ESG Grade } \\
\hline & \multicolumn{3}{|c|}{$\mathbf{N}$} & \multicolumn{2}{|c|}{$A+$} & \multicolumn{3}{|c|}{ A } & \multicolumn{2}{|l|}{ B+ } & \multicolumn{2}{|c|}{ Below B } & \multicolumn{2}{|l|}{ Total } \\
\hline \multicolumn{2}{|c|}{2011} & \multicolumn{2}{|c|}{668} & \multicolumn{2}{|c|}{11} & \multicolumn{3}{|c|}{40} & \multicolumn{2}{|l|}{59} & \multicolumn{2}{|l|}{422} & \multicolumn{2}{|l|}{532} \\
\hline \multicolumn{2}{|c|}{2012} & \multicolumn{2}{|c|}{710} & \multicolumn{2}{|c|}{6} & \multicolumn{3}{|c|}{38} & 81 & & \multicolumn{2}{|l|}{540} & \multicolumn{2}{|l|}{665} \\
\hline \multirow{2}{*}{\multicolumn{2}{|c|}{$\begin{array}{l}2013 \\
2014\end{array}$}} & \multicolumn{2}{|c|}{693} & \multicolumn{2}{|c|}{6} & \multicolumn{3}{|c|}{34} & 91 & & \multicolumn{2}{|l|}{562} & \multicolumn{2}{|l|}{693} \\
\hline & & \multicolumn{2}{|c|}{694} & \multicolumn{2}{|c|}{2} & \multicolumn{3}{|c|}{44} & 88 & & \multicolumn{2}{|l|}{560} & 694 & \\
\hline \multicolumn{2}{|c|}{2015} & 69 & & 1 & & & 27 & & 78 & & 590 & & 696 & \\
\hline 201 & & 71 & & 8 & & & 33 & & 108 & & 564 & & 713 & \\
\hline 201 & & 73 & & 5 & & & 38 & & 116 & & 574 & & 733 & \\
\hline Tot & & 49 & & 39 & & & 254 & & 621 & & 3812 & & 4726 & \\
\hline (Fir & & $(79$ & & $(21$ & & & (87) & & (233) & & (733) & & - & \\
\hline & & & & & & Pane & ( B: B & Factor & rade & & & & & \\
\hline & & nviro & nmen & & & & Social & & & & Gover & nance & & \\
\hline & $\mathrm{A}+$ & A & $\mathrm{B}+$ & $\mathrm{B} \downarrow$ & $\mathrm{A}+$ & A & $\mathrm{B}+$ & $\mathrm{B} \downarrow$ & $S$ & $\mathrm{~A}+$ & A B + & B & $\mathrm{C}$ & $\mathrm{D}$ \\
\hline 2011 & 9 & 37 & 36 & 290 & 11 & 40 & 54 & 426 & - & 14 & 34105 & 338 & 177 & - \\
\hline 2012 & 10 & 29 & 134 & 500 & 15 & 47 & 80 & 564 & - & 11 & 29111 & 380 & 175 & - \\
\hline 2013 & 6 & 36 & 122 & 529 & 10 & 46 & 90 & 547 & - & 7 & 31113 & 300 & 230 & 12 \\
\hline 2014 & 6 & 40 & 135 & 513 & 4 & 59 & 81 & 550 & - & 13 & 30111 & 308 & 223 & 9 \\
\hline 2015 & 5 & 40 & 141 & 510 & 4 & 35 & 96 & 561 & - & 12 & 3790 & 284 & 250 & 23 \\
\hline 2016 & 3 & 62 & 132 & 516 & 33 & 28 & 126 & 526 & - & 32 & 3199 & 298 & 224 & 29 \\
\hline 2017 & 4 & 58 & 144 & 527 & 26 & 50 & 104 & 553 & 1 & 3 & 53153 & 348 & 155 & 20 \\
\hline Total & 43 & 302 & 844 & 3385 & 103 & 305 & 631 & 3727 & 1 & 92 & 245782 & 2256 & 1434 & 93 \\
\hline
\end{tabular}




\subsection{Cost of Equity}

The cost of equity, which is rate of return required by a firm's equity holders, is not directly observed in the market. Thus we need to estimate it with theoretical models. There are two approaches for estimating the cost of equity in academic fields [54]. The first one is the ex-post realized returns approach. This approach assumes that, realized returns are an unbiased estimator of the market's required return. However, several studies have pointed out that the realized returns may not be an appropriate measure of the cost of equity. For example, Fama and French [26] argue that asset pricing models, such as the CAPM, the Fama, and French three-factor model, do not estimate the cost of equity because the models, which use realized returns as a proxy for expected returns, have failed to provide the clear evidence of an inter-relationship between average realized returns and betas because the CAPM uses. Elton [55] also insists that the average realized returns cannot be a proxy for expected returns because an association between realized returns and expected returns are weak. The second one is the ex-ante implied approach. It considers that the cost of equity is implied in the relation between current market prices and analysts' forecasts [11]. Recent studies argue that ex-ante cost of equity is better proxies for the cost of equity. Analysts' forecasts are regarded as a rational proxy of the market's expected future cash flows, while the expected future cash flows cannot be observed directly [29]. In addition, it makes an explicit attempt to isolate the cost of equity effects from the growth and cash flow effects [24]. Also it is particularly useful for the short sample period, while the sample average approach requires such a long sample period to acquire the reliability of the estimation [54].

Based on such discussions, we estimate the implied cost of equity using ex-ante implied approaches. We follow three different models suggested in previous studies $[24,27,56,57]$. In all three models, FEPS ${ }_{t}$ is the three-month average value of the $t$ year ahead EPS estimates announced by securities firms; we re-estimate the cost of equity using median analyst's EPS forecasts. To save space, the results using average value are reported here. The results using median value are similar to those of using average value. FEPS is obtained from FnGuide. $P_{t}$ is the price at $t$, and DPS is the dividend per share at $t$.

Our first measure of the cost of equity is estimated by the Ohlson and Juettner [28] model (OJ model). The OJ model has two advantages. First, it does not need forecasts of book values or return on equity. Second, it is parsimonious; $\gamma$ determines the perpetual growth rate as well as the decay rate of short-term growth as our short-term growth [29]. As suggested by Gode and Mohanram [29] who empirically test the OJ model, we use the average of forecast two-year growth and estimate $\lambda-1$ by the risk-free rate less $3 \%$. Specifically, for each firm $i$ in year $t, k_{O J}$ is calculated as

$$
\mathrm{k}_{\mathrm{OJ}}=A+\sqrt{A^{2}+\frac{F E P S_{t+1}}{P_{t}}\left(g_{2}-(\lambda-1)\right)}
$$

where $A=\frac{1}{2}\left(\lambda-1+\frac{D P S_{1}}{P_{t}}\right), D P S_{1}=D P S_{0}, g_{2}=\frac{F E P S_{t+2}-F E P S_{t+1}}{F E P S_{t+1}}$, and $\lambda-1=r_{f}-0.03$.

The second measure is the PEG model suggested by Easton [30]. This model assumes no dividend payments and is based on short-term earnings forecasts. For each firm $i$ in year $t, k_{P E G}$ is calculated as

$$
\mathrm{P}_{\mathrm{t}}=\frac{F E P S_{t+2}-F E P S_{t+1}}{k_{P E G}^{2}}
$$

The third measure is the MPEG model also suggested by Easton [30]. This model has a clear forecasting horizon of two years, assuming earnings with a constant growth rate. For each firm $i$ in year $t, k_{M P E G}$ is calculated as:

$$
\mathrm{P}_{\mathrm{t}}=\frac{\mathrm{FEPS}_{t+2}+k_{M P E G} \times D P S_{t+1}-F E P S_{t+1}}{k_{M P E G}^{2}} .
$$

Equation (3) requires FEPS $_{\mathbf{t}+2}>F E P S_{t+1}>0$. 
Table 2 reports the summary statistics of the cost of equity estimates. Estimates corresponding to the upper and lower $1 \%$ are excluded. The average annual cost of equity is $15.20 \%$ to $16.35 \%$. The cost of equity is estimated to be lowest in the OJ model and highest in the MPEG model. This result is consistent with those in previous studies [22,30,58].

Table 2. Descriptive statistics for cost of equity estimates.

\begin{tabular}{ccccccccc}
\hline & N & MEAN & STD & MIN & Q1 & MEDIAN & Q3 & MAX \\
\hline $\mathrm{k}_{\text {OJ }}$ & 353 & 15.20 & 6.51 & 2.83 & 10.39 & 13.69 & 18.51 & 40.16 \\
$\mathrm{k}_{\text {PEG }}$ & 408 & 16.35 & 7.40 & 3.41 & 11.07 & 14.59 & 20.71 & 49.95 \\
$\mathrm{k}_{\text {MPEG }}$ & 354 & 15.40 & 5.62 & 3.91 & 11.29 & 14.19 & 18.50 & 34.73 \\
\hline
\end{tabular}

Figure 1 shows the average cost of equity by ESG grade. There is no pattern of monotonous increase or decrease in the cost of equity according to the ESG grade, but costs of equity below B are noticeably higher.

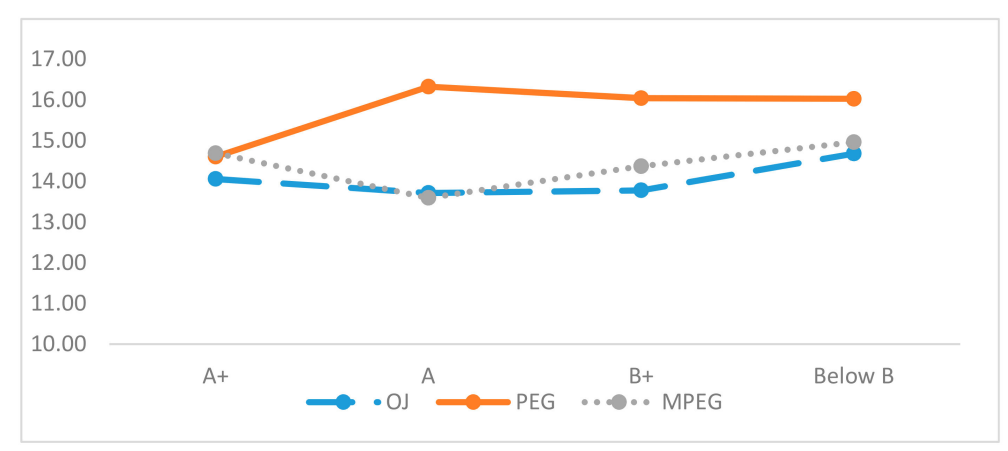

Figure 1. Cost of Equity by ESG Grade.

\subsection{Other Variables}

Table 3 reports the summary statistics for the control variables used in this study. We include firm characteristics, which are known to affect the cost of equity. Book-to-market ratio (BM) is used to capture a firm's growth opportunity [59]. The BM ratio is calculated by dividing the book value of equity in year $t$ by the market value of equity in year $t-1$. Firms with larger BM ratios can be expected to have higher capital costs. Firm size (SIZE) is used as a proxy for firms' information environments. Information asymmetry is mitigated for large firms, due to the high interest shown by media and analysts [60], leading to a negative relationship between firm size and the cost of equity. Firm size is measured as the natural logarithm of total assets at the end of year $t-1$. The market beta (BETA) is expected to be positively related to the cost of equity because it represents volatility against systemic risk. BETA is calculated using the Fama and French three-factor model over a one-year period. If the number of observations is less than 120, they are regarded as missing values. For leverage (LEV), a positive relationship between leverage and cost of equity is expected because a large debt can induce great financial risk. LEV is calculated by dividing the total debt by market capitalization at the end of year $t-1$, following [61]. A high volatility of stock returns (IVOL) indicates greater risk of unfavorable earnings or returns. Park and Kim [16] argue that corporate CSR plays an important role in lowering the cost of equity by reducing idiosyncratic risks. Therefore, it is expected that, idiosyncratic volatility and cost of equity, will be positively related. Idiosyncratic volatility is estimated as the standard deviation of the residuals from the Fama and French three-factor model, using daily returns over a one-year period. If the number of observations is less than 120, they are regarded as missing values. The number of analysts following a firm (ANAL) determines the amount of information available about it. Therefore, a large number of analysts can be expected to have a negative relationship with the cost of equity because they can lower transaction costs and estimation error. ANAL is calculated as the number of analysts who announced forecasts. By contrast, a large standard deviation of analysts' earnings 
forecasts (DISP) can be expected to be positively related to the cost of equity because it increases risk [58,59]. Thus, DISP is calculated as the standard deviation of earnings forecasts. Finally, we control for the long-term growth forecast (LTG). Stocks with high growth rate are generally considered to be riskier, and the long-term growth is expected to be positively associated with the cost of equity [11,29]. LTG is calculated as the difference between one- and two-year-ahead EPS forecast divided by the one-year-ahead EPS forecasts.

Table 3. Descriptive statistics for control.

\begin{tabular}{ccccccccc}
\hline & N & MEAN & STD & MIN & Q1 & MEDIAN & Q3 & MAX \\
\hline BM & 733 & 1.47 & 1.02 & 0.08 & 0.79 & 1.24 & 1.93 & 6.33 \\
SIZE & 733 & 26.97 & 1.56 & 23.91 & 25.91 & 26.74 & 27.86 & 31.49 \\
BETA & 733 & 0.72 & 0.29 & 0.03 & 0.51 & 0.71 & 0.89 & 1.75 \\
LEV & 733 & 2.07 & 2.66 & 0.04 & 0.49 & 1.14 & 2.53 & 17.12 \\
IVOL & 733 & 2.48 & 0.78 & 0.94 & 1.94 & 2.36 & 2.87 & 6.01 \\
ANAL & 733 & 3.69 & 5.48 & 1.00 & 1.00 & 1.00 & 2.71 & 27.14 \\
LTG & 733 & -5.50 & 4.12 & -14.32 & -8.96 & -7.14 & -1.27 & 9.32 \\
DISP & 733 & 3.38 & 1.52 & 1.57 & 2.43 & 2.43 & 3.91 & 8.79 \\
\hline
\end{tabular}

Tables 3 and 4 report summary statistics for the control variables, and correlations, respectively.

Table 4. Correlation of control variables.

\begin{tabular}{ccccccccccccc}
\hline & ESG & E & S & G & BM & SIZE & BETA & LEV & IVOL & ANAL & LTG & DISP \\
\hline ESG & 1.000 & & & & & & & & & & & \\
E & 0.706 & 1.000 & & & & & & & & & & \\
S & 0.821 & 0.604 & 1.000 & & & & & & & & & \\
G & 0.497 & 0.298 & 0.365 & 1.000 & & & & & & & & \\
BM & -0.060 & -0.035 & -0.124 & -0.017 & 1.000 & & & & & & & \\
SIZE & -0.152 & -0.111 & -0.155 & -0.064 & 0.279 & 1.000 & & & & & & \\
BETA & 0.603 & 0.580 & 0.591 & 0.402 & -0.049 & 0.069 & 1.000 & & & & & \\
LEV & 0.228 & 0.250 & 0.219 & 0.100 & 0.131 & -0.146 & 0.264 & 1.000 & & & & \\
IVOL & -0.010 & 0.031 & -0.002 & -0.051 & 0.296 & 0.555 & 0.239 & 0.047 & 1.000 & & & \\
ANAL & -0.180 & -0.168 & -0.173 & -0.276 & 0.074 & -0.096 & -0.339 & 0.230 & 0.128 & 1.000 & & \\
LTG & 0.637 & 0.550 & 0.601 & 0.371 & -0.195 & -0.242 & 0.683 & 0.265 & -0.094 & -0.192 & 1.000 & \\
DISP & 0.252 & 0.215 & 0.253 & 0.225 & 0.084 & -0.168 & 0.298 & 0.265 & -0.076 & -0.034 & 0.319 & 1.000 \\
\hline
\end{tabular}

\section{Empirical Results}

\subsection{Portfolio Analysis}

We constructed portfolios, based on ESG grades, in order to capture the potential differences between the average costs of equity for each portfolio. The portfolios were formed in four ways, according to the ESG grade: Environmental management grade (E), social responsibility management grade (S), and governance grade (G). Specifically, the portfolios were constructed as follows. First, all stocks, included in the sample, have been classified as either a "High" or "Low" portfolio according to the ESG grades at the end of December of year $t$. The High portfolio consists of stocks with grades above $\mathrm{B}+$, while the Low portfolio consists of stocks with grades below $\mathrm{B}$. We then observed the relationship between CSR performance and the cost of equity through the magnitude and significance of the cost of equity of High/Low portfolios at the end of year $t+1$. The cost of equity is estimated using the OJ, PEG, and MPEG models. All portfolios are reconstructed every year.

Table 5 reports the magnitude and significance of the average cost of equity for the portfolios. Panel A presents the cost of equity of the portfolios formed based on ESG grades. We observed that the cost of equity of the High portfolio is lower, regardless of the estimation method used. The annual average cost of equity of the High portfolio ranges from $13.79 \%$ to $16.04 \%$, which is $0.19 \%$ p to $1.09 \%$ p lower than the average cost of equity of the Low portfolio, which ranges from $14.89 \%$ to $16.23 \%$. This result is consistent with previous studies' finding that firms with better CSR performance can finance with a lower cost of equity [11]. 
Table 5. Portfolio analysis.

\begin{tabular}{|c|c|c|c|}
\hline & $\mathrm{k}_{\mathrm{OJ}}$ & $\mathbf{k}_{\text {PEG }}$ & $\mathbf{k}_{\text {MPEG }}$ \\
\hline \multicolumn{4}{|c|}{ Panel A: By Total ESG Grade } \\
\hline High & $\begin{array}{c}13.79 * * * \\
(42.80)\end{array}$ & $\begin{array}{c}16.04^{* * *} \\
(29.58)\end{array}$ & $\begin{array}{c}14.18^{* * *} \\
(73.69)\end{array}$ \\
\hline Low & $\begin{array}{c}14.89^{* * *} \\
(31.69)\end{array}$ & $\begin{array}{c}16.23^{* * *} \\
(41.45)\end{array}$ & $\begin{array}{c}15.26^{* * *} \\
(27.29)\end{array}$ \\
\hline High-Low & $\begin{array}{l}-1.09 * \\
(-2.03)\end{array}$ & $\begin{array}{c}-0.19 \\
(-0.27)\end{array}$ & $\begin{array}{l}-1.08^{*} \\
(-2.18)\end{array}$ \\
\hline \multicolumn{4}{|c|}{ Panel B: By Environmental Grade } \\
\hline High & $\begin{array}{c}13.92 * * * \\
(39.67)\end{array}$ & $\begin{array}{c}16.14 * * * \\
(28.42)\end{array}$ & $\begin{array}{c}14.34^{* * *} \\
(55.36)\end{array}$ \\
\hline Low & $\begin{array}{c}14.74^{* * *} \\
(30.93)\end{array}$ & $\begin{array}{c}16.04^{* * *} \\
(32.65)\end{array}$ & $\begin{array}{c}15.09^{* * *} \\
(26.93)\end{array}$ \\
\hline High-Low & $\begin{array}{c}-0.83 \\
(-1.38)\end{array}$ & $\begin{array}{c}0.10 \\
(0.11)\end{array}$ & $\begin{array}{c}-0.75 \\
(-1.29)\end{array}$ \\
\hline \multicolumn{4}{|c|}{ Panel C: By Social Grade } \\
\hline High & $\begin{array}{c}13.41^{* * *} \\
(39.68)\end{array}$ & $\begin{array}{c}15.69 * * * \\
(26.80)\end{array}$ & $\begin{array}{c}13.82 * * * \\
(90.06)\end{array}$ \\
\hline Low & $\begin{array}{c}15.30 * * * \\
(26.42)\end{array}$ & $\begin{array}{c}16.52 * * * \\
(35.67)\end{array}$ & $\begin{array}{c}15.62 * * * \\
(24.16)\end{array}$ \\
\hline High-Low & $\begin{array}{l}-1.89 * * \\
(-2.60)\end{array}$ & $\begin{array}{c}-0.83 \\
(-1.00)\end{array}$ & $\begin{array}{c}-1.81 \text { ** } \\
(-2.89)\end{array}$ \\
\hline \multicolumn{4}{|c|}{ Panel D: By Governance Grade } \\
\hline High & $\begin{array}{c}13.67^{* * *} \\
(47.65)\end{array}$ & $\begin{array}{c}15.51 * * * \\
(34.21)\end{array}$ & $\begin{array}{l}14.07^{* * *} \\
(109.62)\end{array}$ \\
\hline Low & $\begin{array}{c}15.03^{* * *} \\
(28.48)\end{array}$ & $\begin{array}{c}16.64^{* * *} \\
(37.14)\end{array}$ & $\begin{array}{c}15.43^{* * *} \\
(24.21)\end{array}$ \\
\hline High-Low & $\begin{array}{l}-1.36^{*} \\
(-2.38)\end{array}$ & $\begin{array}{c}-1.13 \\
(-1.66)\end{array}$ & $\begin{array}{l}-1.37^{*} \\
(-2.33)\end{array}$ \\
\hline
\end{tabular}

Note: ${ }^{* * *},{ }^{* *}$, and ${ }^{*}$ denote significance at the $1 \%, 5 \%$, and $10 \%$ levels, respectively.

The results in Panel $\mathrm{C}$ show that firms that earned grades above B+ for social responsibility management can finance the cost of equity at the lowest cost. This result is observed regardless of how the cost of equity is estimated. High portfolio firms can finance at a cost of $13.41 \%$ to $15.69 \%$ per annum, while Low portfolio firms pay $15.30 \%$ to $16.52 \%$ per annum. The difference between the two portfolios is $-0.83 \%$ p to $-1.89 \%$ p, which is statistically significant at the $5 \%$ level. The results in Panel $\mathrm{D}$ are also significant. They show that firms graded above $\mathrm{B}+$ for governance can finance at a cost $-1.13 \% \mathrm{p}$ to $-1.37 \% \mathrm{p}$ lower than firms with lower grades. This result is statistically significant at the $10 \%$ level. This result is consistent with the previous finding that better governance in the Korean stock market leads to a lower cost of equity [58]. However, the result for environmental management provides no evidence of a statistically significant difference.

The result of the portfolio analysis indicates that firms with better CSR performances can finance their cost of equity at low costs. The firms that fulfill their social responsibilities, and have better corporate governance, enjoy particularly low costs.

\subsection{Fama and MacBeth Cross-Sectional Regression}

Next, we conducted a Fama and MacBeth [62] cross-sectional regression analysis, at the individual stock level, in order to check whether the results of the portfolio analysis persist after various factors that may affect the cost of equity are controlled for. The cost of equity at the end of year $t+1$ is the dependent variable, and the other variables at the end of year $t$ are independent variables.

Table 6 reports the regression results. Models (1), (3), and (5) do not include the control variables, in order to allow a direct examination of the relationship between CSR and the cost of equity. Models (2), (4), and (6) examine the relationship between CSR and the cost of equity, while controlling for various factors known to affect the cost of equity. 
Table 6. Fama-MacBeth regression results of cost of equity on ESG grade.

\begin{tabular}{|c|c|c|c|c|c|c|}
\hline & (1) & (2) & (3) & (4) & (5) & (6) \\
\hline & $\mathrm{k}_{\mathrm{OJ}}$ & $\mathrm{k}_{\mathrm{OJ}}$ & $\mathbf{k}_{\mathrm{PEG}}$ & $\mathbf{k}_{\mathrm{PEG}}$ & $\mathbf{k}_{\text {MPEG }}$ & $\mathbf{k}_{\text {MPEG }}$ \\
\hline \multicolumn{7}{|c|}{ Panel A: Effects of ESG grade } \\
\hline ESG & $\begin{array}{l}-0.076 \\
(-1.36)\end{array}$ & $\begin{array}{l}0.030 \text { * } \\
(2.13)\end{array}$ & $\begin{array}{l}-0.004 \\
(-0.06)\end{array}$ & $\begin{array}{l}0.043 \\
(1.29)\end{array}$ & $\begin{array}{l}-0.083 \\
(-1.52)\end{array}$ & $\begin{array}{l}-0.011 \\
(-0.55)\end{array}$ \\
\hline BM & & $\begin{array}{l}0.786^{*} \\
(2.05)\end{array}$ & & $\begin{array}{l}0.006 \\
(0.01)\end{array}$ & & $\begin{array}{l}0.863 * \\
(1.97)\end{array}$ \\
\hline SIZE & & $\begin{array}{c}-0.379^{* * * *} \\
(-4.11)\end{array}$ & & $\begin{array}{l}0.019 \\
(0.10)\end{array}$ & & $\begin{array}{c}-0.418^{*} \\
(-2.41)\end{array}$ \\
\hline BETA & & $\begin{array}{c}3.308^{* * *} \\
(5.45)\end{array}$ & & $\begin{array}{c}3.976^{* * *} \\
(9.46)\end{array}$ & & $\begin{array}{c}2.256^{* * *} \\
(5.67)\end{array}$ \\
\hline LEV & & $\begin{array}{c}1.040 * * \\
(3.47)\end{array}$ & & $\begin{array}{c}1.658^{* * *} \\
(4.43)\end{array}$ & & $\begin{array}{c}0.606^{* *} \\
(3.27)\end{array}$ \\
\hline IVOL & & $\begin{array}{l}-0.039 \\
(-0.10)\end{array}$ & & $\begin{array}{l}0.916 \\
(1.30)\end{array}$ & & $\begin{array}{l}-0.253 \\
(-1.20)\end{array}$ \\
\hline ANAL & & $\begin{array}{c}-0.110^{* * *} \\
(-3.89)\end{array}$ & & $\begin{array}{c}-0.180 \text { *** } \\
(-4.12)\end{array}$ & & $\begin{array}{l}-0.067^{*} \\
(-2.19)\end{array}$ \\
\hline LTG & & $\begin{array}{l}1.852 \\
(1.50)\end{array}$ & & $\begin{array}{l}0.337 \\
(0.67)\end{array}$ & & $\begin{array}{c}3.416^{* *} \\
(3.54)\end{array}$ \\
\hline DISP & & $\begin{array}{l}-0.242 * \\
(-2.41)\end{array}$ & & $\begin{array}{l}-0.117 \\
(-0.61)\end{array}$ & & $\begin{array}{c}-0.162 \text { * } \\
(-2.20)\end{array}$ \\
\hline Adj. $R^{2}$ & 0.014 & 0.281 & 0.011 & 0.269 & 0.017 & 0.438 \\
\hline obs & 1114 & 1114 & 1340 & 1340 & 1104 & 1104 \\
\hline \multicolumn{7}{|c|}{ Panel B: Effects of Environmental grade } \\
\hline Environmental & $\begin{array}{l}-0.057 \\
(-1.08)\end{array}$ & $\begin{array}{l}0.039 * \\
(2.17)\end{array}$ & $\begin{array}{l}0.019 \\
(0.23)\end{array}$ & $\begin{array}{l}0.018 \\
(0.43)\end{array}$ & $\begin{array}{l}-0.056 \\
(-1.11)\end{array}$ & $\begin{array}{c}0.041^{* *} \\
(3.04)\end{array}$ \\
\hline Controls & No & Yes & No & Yes & No & Yes \\
\hline Adj. $R^{2}$ & 0.012 & $0.285^{* * *}$ & 0.015 & $0.274^{* * *}$ & 0.014 & $0.442 * * *$ \\
\hline obs & 1069 & 1069 & 1287 & 1287 & 1054 & 1054 \\
\hline \multicolumn{7}{|c|}{ Panel C: Effects of Social grade } \\
\hline Social & $\begin{array}{c}-0.138 * \\
(-2.07)\end{array}$ & $\begin{array}{l}-0.045 \\
(-1.23)\end{array}$ & $\begin{array}{l}-0.059 \\
(-0.73)\end{array}$ & $\begin{array}{l}-0.040 \\
(-0.76)\end{array}$ & $\begin{array}{c}-0.134 * \\
(-2.23)\end{array}$ & $\begin{array}{c}-0.065^{\text {** }} \\
(-2.93)\end{array}$ \\
\hline Controls & No & Yes & No & Yes & No & Yes \\
\hline Adj. $R^{2}$ & 0.037 & $0.286^{* * *}$ & 0.020 & $0.274^{* * *}$ & 0.038 & $0.442^{* * *}$ \\
\hline obs & 1114 & 1114 & 1340 & 1340 & 1104 & 1104 \\
\hline \multicolumn{7}{|c|}{ Panel D: Effects of Governance grade } \\
\hline Governance & $\begin{array}{l}-0.069 \\
(-1.03)\end{array}$ & $\begin{array}{l}0.047 \\
(1.56)\end{array}$ & $\begin{array}{l}-0.114 \\
(-1.85)\end{array}$ & $\begin{array}{l}-0.027 \\
(-0.80)\end{array}$ & $\begin{array}{l}-0.096 \\
(-1.49)\end{array}$ & $\begin{array}{l}-0.004 \\
(-0.23)\end{array}$ \\
\hline Controls & No & Yes & No & Yes & No & Yes \\
\hline Adj. $R^{2}$ & 0.013 & $0.285^{* * *}$ & 0.014 & $0.270^{* * *}$ & 0.017 & $0.438^{* * *}$ \\
\hline obs & 1114 & 1114 & 1340 & 1340 & 1104 & 1104 \\
\hline
\end{tabular}

Panel A of Table 6 shows that no statistically significant relationship is observed between ESG grades and the cost of equity, regardless of the regression model. Although differing in magnitude and significance, other control variables indicate the predicted signs. Specifically, SIZE, BETA, LEV, and ANAL are significant. The smaller the firm is, the larger the market beta, the higher the leverage ratio, and the smaller the number of analysts following it - which all lead to higher costs of equity. Except for the result in Panel A, the results are similar to those of the portfolio analysis. We find that firms that fulfill their social responsibilities and have better corporate governance can finance their cost of equity at a lower cost. Environmental management does not affect the cost of equity even when the effects of other factors are controlled for.

The results of the empirical analysis are summarized as follows. In the Korean stock market, CSR performance does not directly affect the cost of equity. When distinguishing firms, based on social responsibility and corporate governance, however, we find that high social responsibility and corporate governance levels lead to lower costs of equity. 


\section{Additional Analysis}

In this section, we verify whether the results of the empirical analysis are robust. We re-examine the sample excluding cases where the number of analysts is fewer than five.

We examine the results, excluding cases where the number of analysts reporting the consensus, is fewer than five. A large number of analysts indicates that more information about the firm is available. This is expected to mitigate information asymmetry and reduce the cost of equity. This phenomenon should be particularly apparent for firms with low ESG grades, which have high costs of equity. Table 7 shows that the cost of equity decreases sharply for the Low portfolio. In some cases, the cost of equity is slightly lower than that in the High portfolio. The results of the empirical analysis show that, the statistically significant negative results, between the High and Low portfolios' costs of equity, are mainly due to the high cost of equity of the Low portfolio stocks. However, when these stocks are excluded, the differences in the cost of equity between the High and Low portfolios are not statistically significant. This result is consistent with the results of the Fama and MacBeth [62] cross-sectional regression analysis. Table 8 shows that, in most cases, CSR performance has no statistically significant effect on the cost of equity. The second column of Panel D shows that governance has a significant impact on the cost of equity. The correlation coefficient reported in Table 4 shows that CSR performance is highly correlated with firm size and the number of analysts. Large firms have excellent CSR performance and a large analyst following, which mitigates information asymmetry and lowers the cost of equity. Thus, differences in the cost of equity can be affected by information asymmetry.

Table 7. Portfolio analysis: Excluding cases with fewer than five analysts.

\begin{tabular}{|c|c|c|c|}
\hline & $\mathrm{k}_{\mathrm{OJ}}$ & $\mathbf{k}_{\mathrm{PEG}}$ & $\mathbf{k}_{\text {MPEG }}$ \\
\hline \multicolumn{4}{|c|}{ Panel A: By Total ESG Grade } \\
\hline High & $\begin{array}{c}13.36^{* * *} \\
(45.22)\end{array}$ & $\begin{array}{c}15.71^{* * *} \\
(27.08)\end{array}$ & $\begin{array}{c}13.80^{* * * *} \\
(88.01)\end{array}$ \\
\hline Low & $\begin{array}{c}13.12^{* * *} \\
(25.48)\end{array}$ & $\begin{array}{c}14.74^{* * *} \\
(37.12)\end{array}$ & $\begin{array}{c}13.63^{* * *} \\
(26.83)\end{array}$ \\
\hline High-Low & $\begin{array}{c}0.24 \\
(0.48)\end{array}$ & $\begin{array}{c}0.98 \\
(1.34)\end{array}$ & $\begin{array}{c}0.16 \\
(0.33)\end{array}$ \\
\hline \multicolumn{4}{|c|}{ Panel B: By Environmental Grade } \\
\hline High & $\begin{array}{c}13.11^{* * *} \\
(42.63)\end{array}$ & $\begin{array}{c}15.61 * * * \\
(25.57)\end{array}$ & $\begin{array}{c}13.61^{* * *} \\
(78.36)\end{array}$ \\
\hline Low & $\begin{array}{c}13.15^{* * *} \\
(26.68)\end{array}$ & $\begin{array}{c}14.33^{* * *} \\
(40.82)\end{array}$ & $\begin{array}{c}13.55^{* * *} \\
(29.24)\end{array}$ \\
\hline High-Low & $\begin{array}{l}-0.04 \\
(-0.09)\end{array}$ & $\begin{array}{c}1.27 \\
(1.81)\end{array}$ & $\begin{array}{c}0.05 \\
(0.11)\end{array}$ \\
\hline \multicolumn{4}{|c|}{ Panel C: By Social Grade } \\
\hline High & $\begin{array}{c}13.00^{* * *} \\
(36.97)\end{array}$ & $\begin{array}{c}15.23 * * * \\
(25.85)\end{array}$ & $\begin{array}{c}13.47^{* * *} \\
(58.52)\end{array}$ \\
\hline Low & $\begin{array}{c}13.51^{* * * *} \\
(22.30)\end{array}$ & $\begin{array}{c}15.22 * * * \\
(35.65)\end{array}$ & $\begin{array}{c}13.97^{* * * *} \\
(24.66)\end{array}$ \\
\hline High-Low & $\begin{array}{l}-0.51 \\
(-0.74)\end{array}$ & $\begin{array}{c}0.01 \\
(0.02)\end{array}$ & $\begin{array}{c}-0.49 \\
(-0.79)\end{array}$ \\
\hline \multicolumn{4}{|c|}{ Panel D: By Governance Grade } \\
\hline High & $\begin{array}{c}13.44 * * * \\
(49.20)\end{array}$ & $\begin{array}{c}15.49^{* * *} \\
(28.65)\end{array}$ & $\begin{array}{c}13.79^{* * *} \\
(89.12)\end{array}$ \\
\hline Low & $\begin{array}{c}13.09 * * * \\
(26.21)\end{array}$ & $\begin{array}{c}15.28^{* * *} \\
(34.19)\end{array}$ & $\begin{array}{c}13.71^{* * *} \\
(30.13)\end{array}$ \\
\hline High-Low & $\begin{array}{c}0.34 \\
(0.78)\end{array}$ & $\begin{array}{c}0.21 \\
(0.30)\end{array}$ & $\begin{array}{c}0.08 \\
(0.21)\end{array}$ \\
\hline
\end{tabular}

Note: ${ }^{* * * * *}$, and $*$ denote significance at the $1 \%, 5 \%$, and $10 \%$ levels, respectively. 
Table 8. Fama-MacBeth Regression Results of Cost of Equity on ESG grade: Excluding cases with fewer than five analysts.

\begin{tabular}{|c|c|c|c|c|c|c|}
\hline & (1) & (2) & (3) & (4) & (5) & (6) \\
\hline & $\mathbf{k}_{0}$ & $\mathbf{k}_{0}$ & $\mathbf{k}_{\mathrm{PEG}}$ & $\mathrm{k}_{\text {PEG }}$ & $\mathbf{k}_{\text {MPEG }}$ & $\mathbf{k}_{\text {MPEG }}$ \\
\hline \multicolumn{7}{|c|}{ Panel A: Effects of ESG grade } \\
\hline ESG & $\begin{array}{l}0.038 \\
(0.66)\end{array}$ & $\begin{array}{l}0.029 \\
(0.94)\end{array}$ & $\begin{array}{l}0.095 \\
(1.28)\end{array}$ & $\begin{array}{l}0.043 \\
(1.27)\end{array}$ & $\begin{array}{l}0.025 \\
(0.44)\end{array}$ & $\begin{array}{l}-0.008 \\
(-0.45)\end{array}$ \\
\hline $\mathrm{BM}$ & & $\begin{array}{l}0.834^{*} \\
(2.33)\end{array}$ & & $\begin{array}{c}-1.086 * \\
(-2.38)\end{array}$ & & $\begin{array}{c}1.405^{* * *} \\
(5.43)\end{array}$ \\
\hline SIZE & & $\begin{array}{l}-0.342 \\
(-0.93)\end{array}$ & & $\begin{array}{l}0.472 \\
(0.77)\end{array}$ & & $\begin{array}{l}0.005 \\
(0.02)\end{array}$ \\
\hline BETA & & $\begin{array}{c}2.499^{* * *} \\
(5.41)\end{array}$ & & $\begin{array}{c}3.579^{* * * *} \\
(5.56)\end{array}$ & & $\begin{array}{c}1.580^{* * *} \\
(4.25)\end{array}$ \\
\hline LEV & & $\begin{array}{c}0.725^{*} \\
(2.08)\end{array}$ & & $\begin{array}{c}1.825 * * \\
(3.67)\end{array}$ & & $\begin{array}{l}0.138 \\
(0.68) \\
\end{array}$ \\
\hline IVOL & & $\begin{array}{l}-0.393 \\
(-0.73)\end{array}$ & & $\begin{array}{l}1.455 \\
(1.18)\end{array}$ & & $\begin{array}{c}-0.353^{* * * *} \\
(-6.19)\end{array}$ \\
\hline ANAL & & $\begin{array}{l}-0.052 \\
(-0.76)\end{array}$ & & $\begin{array}{c}-0.155^{* *} \\
(-2.52)\end{array}$ & & $\begin{array}{l}-0.015 \\
(-0.46)\end{array}$ \\
\hline LTG & & $\begin{array}{c}2.705 * \\
(1.95)\end{array}$ & & $\begin{array}{l}-0.106 \\
(-0.27)\end{array}$ & & $\begin{array}{c}6.151^{* *} \\
(2.91)\end{array}$ \\
\hline DISP & & $\begin{array}{l}0.142 \\
(0.81)\end{array}$ & & $\begin{array}{l}0.287 \\
(0.94)\end{array}$ & & $\begin{array}{l}-0.269 \\
(-1.88)\end{array}$ \\
\hline $\begin{array}{c}\text { Adj.R2 } \\
\text { obs }\end{array}$ & $\begin{array}{c}0.007 \\
644\end{array}$ & $\begin{array}{c}0.313^{* * * *} \\
644\end{array}$ & $\begin{array}{c}0.008 \\
764\end{array}$ & $\begin{array}{c}0.277^{* * * *} \\
764\end{array}$ & $\begin{array}{c}0.010 \\
640\end{array}$ & $\begin{array}{c}0.522 * * * \\
640\end{array}$ \\
\hline \multicolumn{7}{|c|}{ Panel B: Effects of Environmental grade } \\
\hline Environmental & $\begin{array}{l}0.024 \\
(0.48)\end{array}$ & $\begin{array}{l}-0.019 \\
(-0.71)\end{array}$ & $\begin{array}{l}0.117 \\
(1.84)\end{array}$ & $\begin{array}{l}-0.022 \\
(-0.53)\end{array}$ & $\begin{array}{l}0.024 \\
(0.53)\end{array}$ & $\begin{array}{l}0.014 \\
(0.92)\end{array}$ \\
\hline Controls & No & Yes & No & Yes & No & Yes \\
\hline Adj. $R^{2}$ & 0.008 & $0.296^{* * *}$ & 0.012 & $0.287^{* * *}$ & 0.009 & $0.503^{* * *}$ \\
\hline obs & 625 & 625 & 743 & 743 & 621 & 621 \\
\hline \multicolumn{7}{|c|}{ Panel C: Effects of Social grade } \\
\hline Social & $\begin{array}{l}-0.034 \\
(-0.56)\end{array}$ & $\begin{array}{l}-0.028 \\
(-0.68)\end{array}$ & $\begin{array}{l}0.014 \\
(0.19)\end{array}$ & $\begin{array}{l}-0.033 \\
(-0.79)\end{array}$ & $\begin{array}{l}-0.033 \\
(-0.62)\end{array}$ & $\begin{array}{l}-0.037 \\
(-1.27)\end{array}$ \\
\hline Controls & No & Yes & No & Yes & No & Yes \\
\hline Adj. $R^{2}$ & 0.017 & $0.318^{* * *}$ & 0.010 & $0.282^{* * *}$ & 0.017 & $0.525^{* * *}$ \\
\hline obs & 644 & 644 & 764 & 764 & 640 & 640 \\
\hline \multicolumn{7}{|c|}{ Panel D: Effects of Governance grade } \\
\hline Governance & $\begin{array}{l}0.049 \\
(0.78)\end{array}$ & $\begin{array}{c}0.077^{* *} \\
(2.76)\end{array}$ & $\begin{array}{l}-0.026 \\
(-0.43)\end{array}$ & $\begin{array}{l}-0.028 \\
(-0.49)\end{array}$ & $\begin{array}{l}0.021 \\
(0.40)\end{array}$ & $\begin{array}{l}0.018 \\
(1.43)\end{array}$ \\
\hline Controls & No & Yes & No & Yes & No & Yes \\
\hline Adj. $R^{2}$ & 0.010 & $0.315^{* * *}$ & -0.001 & $0.281^{* * *}$ & 0.008 & $0.520^{* * *}$ \\
\hline obs & 644 & 644 & 764 & 764 & 640 & 640 \\
\hline
\end{tabular}

\section{Conclusions}

This study presents empirical evidence on the role of CSR in the Korean stock market. We analyzed how CSR affects the cost of equity by considering three dimensions of CSR activities: Environmental management, socially responsible management, and corporate governance. The empirical results show that, socially responsible management significantly reduces the cost of equity. Firms with higher levels of socially responsible management pay costs of equity $1.13 \%$ to $1.37 \%$ lower per annum, than firms with lower levels. Corporate governance also marginally affects the cost of equity. On the other hand, environmental management has no impact on the cost of equity. These results are significant, even after several factors known to affect the cost of equity are controlled for.

Our study provides guidance for financial managers of firms, that are considering conducting, or are already conducting, CSR activities. Enhancing socially responsible management and corporate governance can increase firm value in Korea by reducing the cost of equity, all else being equal. 
Focusing on socially responsible management will produce the greatest reduction in the cost of equity, while environmental management is not a significant factor.

Our findings also imply that investors tolerate lower returns from firms that are more highly engaged in CSR activities, because they can expect sustainable incomes from such firms. Thus, investors consider, not only the potential for high returns in the short run, but also the sustainability of firm performance over the long run.

Finally, a reliable indicator like the KLD index is required to be developed in order to measure firms' CSR performance precisely in the Korea. Although KCGS has measured and published the CSR performance of most of the stocks listed on the Korean stock market, it relies on what corporations report or voluntary disclosure, making it difficult to accurately measure CSR performance.

This study contributes to the CRS-related literature, by focusing on the Korean stock market, which is increasingly interested in firms' CSR activities. We analyze, not only the CSR performance and firm value, but also which CSR activities have more influence on the firm value. Meanwhile, this paper has some limitations. First, even though we have tried to analyze as many firms as possible to reduce sampling bias, there are still many firms that are excluded from the KCGS evaluation. Second, we analyzed the effect of CSR on the cost of equity. Future studies can extend our approach to cost of debt and cost of capital. Finally, we concentrated on the Korean stock market, but further studies can be extended to Asian emerging markets and compare the results. These limitations can be addressed in further studies.

Author Contributions: The authors provided the following contributions to this paper. Software, Y.O.; formal analysis, Y.O.; investigation, Y.O.; data curation, Y.O.; writing—original draft preparation, Y.O.; methodology, J.K.; validation, J.K.; writing - review and editing, J.K.; supervision, J.K.; project administration, J.K.

Funding: This work was supported by the Ministry of Education of the Republic of Korea and the National Research Foundation of Korea (NRF-2016S1A5A8019621).

Conflicts of Interest: The authors declare no conflict of interest.

\section{References}

1. Guenster, N.; Bauer, R.; Derwall, J.; Koedijk, K. The economic value of corporate eco-efficiency. Eur. Financ. Manag. 2011, 17, 679-704. [CrossRef]

2. McWilliams, A.; Siegel, D. Corporate social responsibility: A theory of the firm perspective. Acad. Manag. Rev. 2001, 26, 117-127. [CrossRef]

3. Hill, R.P.; Ainscough, T.; Shank, T.; Manullang, D. Corporate social responsibility and socially responsible investing: A global perspective. J. Bus. Ethics 2007, 70, 165-174. [CrossRef]

4. Feldman, S.J.; Soyka, P.A.; Ameer, P.G. Does Improving a Firm's Environmental Management System and Environmental Performance Result in a Higher Stock Price? J. Investig. 1997, 6, 87-97. [CrossRef]

5. Jiao, Y. Stakeholder welfare and firm value. J. Bank. Financ. 2010, 34, 2549-2561. [CrossRef]

6. Orlitzky, M.; Schmidt, F.L.; Rynes, S.L. Corporate social and financial performance: A meta-analysis. Organ. Stud. 2003, 24, 403-441. [CrossRef]

7. Brammer, S.; Brooks, C.; Pavelin, S. Corporate social performance and stock returns: UK evidence from disaggregate measures. Financ. Manag. 2006, 35, 97-116. [CrossRef]

8. Hamilton, S.; Jo, H.; Statman, M. Doing well while doing good? The investment performance of socially responsible mutual funds. Financ. Anal. J. 1993, 49, 62-66. [CrossRef]

9. Nelling, E.; Webb, E. Corporate social responsibility and financial performance: The "virtuous circle" revisited. Rev. Quant. Financ. Account. 2009, 32, 197-209. [CrossRef]

10. Renneboog, L.; Ter Horst, J.; Zhang, C. Socially responsible investments: Institutional aspects, performance, and investor behavior. J. Bank. Financ. 2008, 32, 1723-1742. [CrossRef]

11. El Ghoul, S.; Guedhami, O.; Kwok, C.C.; Mishra, D.R. Does corporate social responsibility affect the cost of capital? J. Bank. Financ. 2011, 35, 2388-2406. [CrossRef]

12. Seo, S.; Choi, J. The Relationship between CSR and WACC and Firm Value focused on the KEJI individual Index. Korean Int. Account. Rev. 2015, 64, 1-26. 
13. Jang, J.-I.; Choi, H.-S. The Relation between Corporate Social Responsibility and Financial Performance. Korean J. Bus. Adm. 2010, 23, 633-648.

14. Chon, M.L. Corporate Social Responsibility and the Cost of Equity Capital. Account. Inf. Rev. 2012, 30, 289-312.

15. Min, J.H.; Kim, B.; Ha, S. The Impact of Firms' Environmental, Social, and Governancial Factors for Sustainability on Their Stock Returns and Values. J. Korean Oper. Res. Manag. Sci. Soc. 2014, 39, $33-49$. [CrossRef]

16. Park, J.; Kim, Y. The Effect of Earnings Persistence on Corporate Social Responsibility (CSR)—A Comparative Study of Medium-sized Firms and Large Firms. Asia Pac. J. Bus. Commer. 2018, 10, 44-58.

17. Shin, J.Y.; Suh, C.W.; Park, J.I. The Effect of Corporate Governance on the Association between Earnings and Credit Ratings. Korean Manag. Rev. 2012, 41, 1309-1345.

18. Lee, J.; Kim, J. A Study on Relationship between Corporate Values and Corporate Governance, Social and Environmental Evaluation Index. Rev. Account. Policy Stud. 2013, 18, 81-99.

19. Hwan, Y.; Choul, M. The Impact of Default Risk on Corporate Social Responsibility: Evidence from Korean Firms. J. Ind. Econ. Bus. 2014, 27, 2103-2115.

20. Yoon, B.; Lee, J.; Byun, R. Does ESG Performance Enhance Firm Value? Evidence from Korea. Sustainability 2018, 10, 3635. [CrossRef]

21. Graham, J.R.; Harvey, C.R.; Rajgopal, S. The economic implications of corporate financial reporting. J. Account. Econ. 2005, 40, 3-73. [CrossRef]

22. Botosan, C.A. Disclosure level and the cost of equity capital. Account. Rev. 1997, 323-349.

23. La Porta, R.; Lopez-de-Silanes, F.; Shleifer, A.; Vishny, R. Investor protection and corporate valuation. J. Financ. 2002, 57, 1147-1170. [CrossRef]

24. Hail, L.; Leuz, C. International differences in the cost of equity capital: Do legal institutions and securities regulation matter? J. Account. Res. 2006, 44, 485-531. [CrossRef]

25. Lee, W.H.; Choe, S.M. Estimating the Implied Cost of Capital through a Theoretical Corporate Valuation Model. Korean J. Financ. Stud. 2003, 32, 31-58.

26. Fama, E.F.; French, K.R. Industry costs of equity. J. Financ. Econ. 1997, 43, 153-193. [CrossRef]

27. Pástor, L.; Sinha, M.; Swaminathan, B. Estimating the intertemporal risk-return tradeoff using the implied cost of capital. J. Financ. 2008, 63, 2859-2897. [CrossRef]

28. Ohlson, J.A.; Juettner-Nauroth, B.E. Expected EPS and EPS growth as determinantsof value. Rev. Account. Stud. 2005, 10, 349-365. [CrossRef]

29. Gode, D.; Mohanram, P. Inferring the cost of capital using the Ohlson-Juettner model. Rev. Account. Stud. 2003, 8, 399-431. [CrossRef]

30. Easton, P.D. PE ratios, PEG ratios, and estimating the implied expected rate of return on equity capital. Account. Rev. 2004, 79, 73-95. [CrossRef]

31. Campbell, T.L.; Keys, P.Y. Corporate governance in South Korea: The chaebol experience. J. Corp. Financ. 2002, 8, 373-391. [CrossRef]

32. Joh, S.W. Corporate governance and firm profitability: Evidence from Korea before the economic crisis. J. Financ. Econ. 2003, 68, 287-322. [CrossRef]

33. Kim, B.; Lee, I. Agency problems and performance of Korean companies during the Asian financial crisis: Chaebol vs. non-chaebol firms. Pac. Basin Financ. J. 2003, 11, 327-348. [CrossRef]

34. Bae, K.-H.; Kang, J.-K.; Kim, J.-M. Tunneling or Value Added? Evidence from Mergers by Korean Business Groups. J. Financ. 2002, 57, 2695-2740. [CrossRef]

35. Shin, H.-H.; Park, Y.S. Financing constraints and internal capital markets: Evidence from Korean 'chaebols'. J. Corp. Financ. 1999, 5, 169-191. [CrossRef]

36. Kato, T.; Kim, W.; Lee, J.H. Executive compensation, firm performance, and Chaebols in Korea: Evidence from new panel data. Pac. Basin Financ. J. 2007, 15, 36-55. [CrossRef]

37. Hong, S. Chaebol Firms' Donation Activities and Firm Values. Sustainability 2019, 11, 2417. [CrossRef]

38. Park, S.Y.; Jung, H. The Effect of Managerial Ability on Future Stock Price Crash Risk: Evidence from Korea. Sustainability 2017, 9, 2334. [CrossRef]

39. Gibson, M.S. Is Corporate Governance Ineffective in Emerging Markets? J. Financ. Quant. Anal. 2003, 38, 231-250. [CrossRef]

40. Statman, M.; Glushkov, D. The wages of social responsibility. Financ. Anal. J. 2009, 65, 33-46. [CrossRef] 
41. Gompers, P.; Ishii, J.; Metrick, A. Corporate governance and equity prices. Q. J. Econ. 2003, 118, 107-156. [CrossRef]

42. Kempf, A.; Osthoff, P. The effect of socially responsible investing on portfolio performance. Eur. Financ. Manag. 2007, 13, 908-922. [CrossRef]

43. Eccles, R.G.; Ioannou, I.; Serafeim, G. The impact of corporate sustainability on organizational processes and performance. Manag. Sci. 2014, 60, 2835-2857. [CrossRef]

44. Halvarsson, J.; Zhan, A. Corporate Social Responsibility and the Cost of Capital Is CSR Priced in the Swedish Capital Market? Bachelor's Thesis, Stockholm School of Economics, Stockholm, Sweden, 2015.

45. Xu, S.; Liu, D.; Huang, J. Corporate social responsibility, the cost of equity capital and ownership structure: An analysis of Chinese listed firms. Aust. J. Manag. 2015, 40, 245-276. [CrossRef]

46. Hong, H.; Kacperczyk, M. The price of sin: The effects of social norms on markets. J. Financ. Econ. 2009, 93, 15-36. [CrossRef]

47. Humphrey, J.E.; Lee, D.D.; Shen, Y. Does it cost to be sustainable? J. Corp. Financ. 2012, 18, $626-639$. [CrossRef]

48. Guerard, J.B., Jr. Is there a cost to being socially responsible in investing? J. Forecast. 1997, 16, 475-490. [CrossRef]

49. Bauer, R.; Koedijk, K.; Otten, R. International evidence on ethical mutual fund performance and investment style. J. Bank. Financ. 2005, 29, 1751-1767. [CrossRef]

50. Malik, M. Value-Enhancing Capabilities of CSR: A Brief Review of Contemporary Literature. J. Bus. Ethics 2015, 127, 419-438. [CrossRef]

51. Graves, S.B.; Waddock, S.A. Institutional Owners and Corporate Social Performance. Acad. Manag. J. 1994, 37, 1034-1046.

52. Jo, H.; Harjoto, M.A. The Causal Effect of Corporate Governance on Corporate Social Responsibility. J. Bus. Ethics 2012, 106, 53-72. [CrossRef]

53. Kim, Y.; Park, M.S.; Wier, B. Is Earnings Quality Associated with Corporate Social Responsibility? Account. Rev. 2012, 87, 761-796. [CrossRef]

54. Reverte, C. The Impact of Better Corporate Social Responsibility Disclosure on the Cost of Equity Capital: Corporate Social Responsibility Disclosure and Cost of Capital. Corp. Soc. Responsib. Environ. Manag. 2012, 19, 253-272. [CrossRef]

55. Elton, E.J. Presidential Address: Expected Return, Realized Return, and Asset Pricing Tests. J. Financ. 1999, 54, 1199-1220. [CrossRef]

56. Chen, K.C.; Chen, Z.; Wei, K.J. Legal protection of investors, corporate governance, and the cost of equity capital. J. Corp. Financ. 2009, 15, 273-289. [CrossRef]

57. Hail, L.; Leuz, C. Cost of capital effects and changes in growth expectations around US cross-listings. J. Financ. Econ. 2009, 93, 428-454. [CrossRef]

58. Byun, H.Y.; Kwak, S.K.; Hwang, L.S. The implied cost of equity capital and corporate governance practices. Asia-Pac. J. Financ. Stud. 2008, 37, 139-184.

59. Gebhardt, W.R.; Lee, C.M.; Swaminathan, B. Toward an implied cost of capital. J. Account. Res. 2001, 39, 135-176. [CrossRef]

60. Bowen, R.M.; Chen, X.; Cheng, Q. Analyst coverage and the cost of raising equity capital: Evidence from underpricing of seasoned equity offerings. Contemp. Account. Res. 2008, 25, 657-700. [CrossRef]

61. Fama, E.F.; French, K.R. The cross-section of expected stock returns. J. Financ. 1992, 47, 427-465. [CrossRef]

62. Fama, E.F.; MacBeth, J.D. Risk, return, and equilibrium: Empirical tests. J. Polit. Econ. 1973, 607-636. [CrossRef]

(C) 2019 by the authors. Licensee MDPI, Basel, Switzerland. This article is an open access article distributed under the terms and conditions of the Creative Commons Attribution (CC BY) license (http://creativecommons.org/licenses/by/4.0/). 